\title{
SRUMB - primele perspective ultrasonografice în 2019
}

Începem cu încredere noul an 2019, cel deal XXII-lea al existenței Societății Române de Ultrasonografie în Medicină și Biologie (SRUMB), în ecourile ultimelor două cursuri Endorsed și Euroson sub egida EFSUMB și în pregătirea importantelor manifestări științifice ale acestui an. Cursul Endorsed "Contrast enhanced ultrasound", organizat în 22 noiembrie 2018, de către Centrul de formare în ultrasonografie Timișoara, totodată Centru de excelență al WFUMB, a cuprins, în prima parte, abordarea complexă și completă a problematicii utilizării produșilor de contrast în ultrasonografie - Ghidurile EFSUMB în problema și diagnosticul cu produși de contrast în procesele focale hepatice benigne și maligne, în procesele pancreatice, renale, precum și în alte aplicații, în practica clinică. În cea de-a doua parte cursul a prezentat o sesiune practică de cazuri clinice de mare interes pentru cursanți.

În continuare, în zilele de 23 - 24 noiembrie 2018 la Timișoara a fost organizat cursul Euroson "Liver elastography”, care, după ilustrarea principiilor elastografiei, a prezentat explorarea non-invazivă elastografică a steatozei și fibrozei hepatice, precum și rolul elastografiei în diagnosticul hipertensiunii portale semnificative și al varicelor esofagiene. În cea de-a doua zi a cursului, după prezentarea ghidurilor EFSUMB în practica elastografiei, elaborate în 2017, au fost abordate afecțiunile hepatice colestatice și leziunile focale hepatice, principalele tehnici de elastografie share wave și strain, precum și principalele erori și capcane în practica elastografiei. În continuare au fost prezentate principiile diagnosticului elastografic în ficatul gras non-alcoolic, hipertensiunea portala și în urmărirea pacienților adulți cu patologie cronică hepatică. Practica elastografiei în evaluarea populației pediatrice, abordarea relației de cost eficiență pentru utilizarea elastografiei în raport cu utilizarea RMN, a testelor bio- logice, precum și a biopsiei hepatice în studiul densității hepatice, precum și alegerea tehnicilor optime elastografice în practică sau analiza oportunității screeningului prin elastografie au fost teme noi cu numeroase referințe practice. În ambele zile cursanții au dezvoltat sesiuni hands on în practica principalelor tehnici elastografice.

Cursul Sono-Derm "Dermatologic ultrasound course" organizat de Universitatea de Medicină și Farmacie "Iuliu Hațieganu" din Cluj, sub egida SRUMB, a fost o premieră în domeniu, în care un grup de lectori internaționali de renume invitați, alături de un grup de specialiști clujeni au prezentat, din perspectiva diagnosticului dermatologic, principalele informații necesare abordării chirurgicale. Astfel după prezentarea echipamentului necesar, a tehnicii, dar și a principalelor artefacte și erori, a aplicării elastografiei și ultrasonografiei cu produși de contrast în dermatologie, au fost expuse principalele aspecte teoretice și practice în diagnosticul proceselor focale subcutanate benigne, dar și în leziunile maligne melanomatoase și non-melanomatoase. În a doua zi au fost prezentate patologia vasculară și patologia inflamatorie cronică, cu implicare tegumentară, dar și aplicații în cosmetologie sau în evaluarea eficacității terapeutice a procesului de senescență cutanată. De un mare interes s-au bucurat, în atenția participanților, sesiunile practice de cazuri clinice și examinări hands-on cu echipamente ultrasonografice dedicate.

Cea de-a XXII- a ediție a conferinței Naționale a SRUMB va aduce în ziua preconferință organizarea a patru cursuri cu tematica de interes în patologia abdominală oncologică, nefro-urologică, dar și ultrasonografia vasculară - Doppler și CEUS - pentru începători și avansați sau ultrasonografia toracică. În zilele conferinței - 10 și 11 mai 2019 - vor fi organizate în paralel patru sesiuni științifice concomitent cuprinzând mese rotunde, unele tradiționale, cum sunt US pediatrică, mamară, musculoscheletală, prezentarea ghidurilor EFSUMB sau sesiunile de prezentări de cazuri clinic-ecografice. Ca în fiecare an participanții sunt invitați în competiții dotate cu premii ale SRUMB: sesiunea de prezentări originale, video, precum și sesiunea poster, între care o secțiune aparte va fi cea pentru tânăr autor, sub 35 de ani. Vor fi selecționate și alte teme de interes propuse: US în pancreatologie, endocrinologie, US perinatală, intervențională, US structurilor moi superficiale.

La sfârșitul lunii mai numeroși practicieni români vor participa la Congresul European de Ultrasonografie EUROSON, al EFSUMB, organizat la Granada, Spania și, în foarte scurt timp apoi, la cursurile și sesiunile maraton de Ultrasonografie, organizate la Timișoara, în cadrul Simpozionului Național al Societății Române de Gastroenterologie, Endoscopie digestivă și Hepatologie.

Dorim succes deplin tuturor participărilor românești în manifestări științifice de ultrasonografie și un an fructuos în distincții și premii.

Prof. Viorela Enăchescu

Președinte executiv al SRUMB 